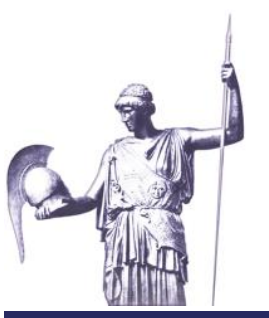

Editorial
Connections: The Quarterly Journal

ISSN 1812-1098, e-ISSN1812-2973

Crone and Hansen, Connections QJ 16, no. 1 (2017): 5-6

https://doi.org/10.11610/Connections.16.1.00

\title{
Disunity in Global Jihad: A Preface
}

\section{Manni Crone and Flemming Splidsboel Hansen}

Danish Institute for International Studies, http://www.diis.dk

As this special issue on "Disunity in global Jihad" goes into print in January 2017, the Islamic State (IS) is facing a possible military defeat throughout its territory in Northern Iraq and Syria. Yet, at the same time, it has proudly claimed responsibility for the 19 December 2016 lorry attack on a Christmas market in Berlin and the 1 January 2017 attack on a nightclub in Istanbul. Experts warn that as the self-proclaimed IS caliphate is crumbling, the organization may re-direct its attention, through its many supporters, to carrying out still more terrorist attacks throughout large parts of the rest of the world, including of course in the West.

The heavy focus in the Western media on IS has pushed al-Qaeda (AQ), until recently the subject of most of our counter-terrorist thinking and efforts, into the background of our collective consciousness. AQ, now serving mostly as a unifying brand for the smaller groups operating under its name, is still active, however, and in several places locked in a bloody conflict with IS. The possible military defeat of IS in Northern Iraq and Syria by a combination of local and foreign troops may pave the way for $A Q$ to re-assert itself on the global Jihadist scene. Several of the contributions in the special issue suggest such a development as they discuss the rivalry of IS and AQ in several theaters.

The special issue is based on work done mainly at the Danish Institute for International Studies (DIIS), where, as a consequence of the emergence of especially IS, the more traditional counter-terrorist studies have been complemented by more recent counter-radicalization research. Special funding by several Danish ministries has allowed DIIS to build up a consid- 
erable research base, part of which is now offered to the readers of Connections. The contributors express their gratitude to the Editorial Board of the PfP Consortium for the opportunity to launch this special issue.

Copenhagen, 4 January 2017

\section{About the Guest Editors}

Dr. Manni Crone PhD, is Senior Researcher at the Danish Institute for International Studies. Her current research focuses on terrorism and counterterrorism in Europe, North Africa and Sahel. Recent publications include "Radicalization revisited," International Affairs 92:3 (2016) and "French interventionism in the post-American MENA-region: filling a void?," in Between Regional Autonomy and Intervention: New Conflict Dynamics in the Middle East and North Africa (DIIS, 2017).

Dr. Flemming Splidsboel Hansen is a Senior Researcher and Coordinator of the International Security Research Unit at DIIS. Before joining DIIS, he has held positions in the OSCE Office in Tajikistan, at various universities and in the Danish military. His research interests include Russian identity politics, Russian disinformation campaigns and integration in the post-Soviet space. Flemming Splidsboel Hansen is the corresponding guest editor and he may be contacted at fsha@diis.dk. 